\title{
Notes on the distribution of some species of Lepidoptera in Kazakhstan
}

\author{
Mario Langourov ${ }^{1}$, Nikolay Simov ${ }^{2}$, Stanislav Abadjiev ${ }^{3}$
}

National Museum of Natural History, Bulgarian Academy of Sciences, 1 Tsar Osvoboditel Blvd, 1000 Sofia, Bulgaria, [1] langourov@nmnhs.com, [2] simov@nmnhs.com, [3] abadjiev@nmnhs.com

\begin{abstract}
The paper presents results of an entomological expedition carried out in the southern parts of Kazakhstan in May 2015. This expedition was conducted within a joint team project of the Department of Entomology, Faculty of Biology, Saint Petersburg State University, and the National Museum of Natural History, Bulgarian Academy of Sciences. The paper includes a list of 17 recorded species of Lepidoptera with comments on their distribution.
\end{abstract}

Keywords: butterfly, distribution, Lepidoptera, Kazakhstan

During the second half of May 2015 a small entomological expedition was carried out in the southern parts of Kazakhstan within the frame of a joint project of the Department of Entomology, Faculty of Biology, Saint Petersburg State University, and the National Museum of Natural History, Bulgarian Academy of Sciences, Sofia. Numerous desert and steppe habitats in different geographic regions of Kazakhstan were visited during the expedition: Karatau Mts, Syrdarya River Valley, Kyzylkum Desert, Dar'yalyktakyr Plain, Saryarka-Kazakhskiy Melkosopochnik, Boraldaytau Ridge, Betpak-Dala Steppe, Taukum Sands, and Balkhash Lake Shore (Fig. 1). While studying the very rich Central Asian fauna of Hemiptera, Fedor Konstantinov (Saint Petersburg) and Nikolay Simov (Sofia) had collected several new and interesting species of Lepidoptera, primarily butterflies. The present paper summarises these data and includes a list of recorded species with comments on their distribution.

Very few articles with precise localities were published before "The Butterflies of Kazakhstan" (Tshikolovets et al., 2016). One of them also covers the spring aspect but only from the surroundings of Kapshagay Reservoir (Korb \& Egorov, 2012). All previous records were published in Tshikolovets et al. (2016), together with new ones and precise distributional maps.

\section{Erebidae: Arctiinae}

Amata caspia (Staudinger, 1877) - [waypoint 13] (Fig. 3) Karagandy Province, Balkhash Lake Shore, $10 \mathrm{~km}$ E from Gulshat Village, $46^{\circ} 35.600^{\prime} \mathrm{N}, 7^{\circ} 29.275^{\prime} \mathrm{E}$, 341 m, 29 May $2015-1 \delta^{\lambda}$. Known from Kazakhstan (Ignatyev \& Zolotuhin, 2005: 45).

\section{Pieridae}

Colias erate (Esper, [1805]) - [waypoint 7] South Kazakhstan Province, Syrdarya River Valley, $30 \mathrm{~km}$ WSW of Arys Village, 42 $15.340^{\prime} \mathrm{N}, 68^{\circ} 31.997^{\prime} \mathrm{E}$, 209 m, 21 May 2015 - 1 §. Widespread in Kazakhstan (Tshikolovets et al., 2016: 112).

\section{Lycaenidae}

Cigaritis epargyros (Eversmann, 1854) - [waypoint 9] (Fig. 4) Kyzylorda Province, Syrdarya Valley/ Kyzylkum Desert, $11 \mathrm{~km}$ WSW of Besh-Aryk Vil-

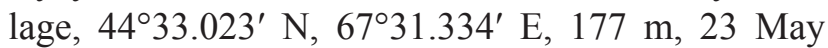

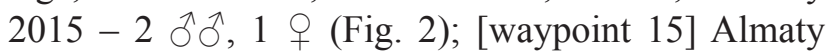
Province, Taukum Sands, $3 \mathrm{~km} \mathrm{~W}$ from Topar Village, $45^{\circ} 02.192^{\prime} \mathrm{N}, 74^{\circ} 58.545^{\prime} \mathrm{E}, 363 \mathrm{~m}, 31$ May $2015-2$ 
Mario Langourov, Nikolay Simov, Stanislav Abadjiev

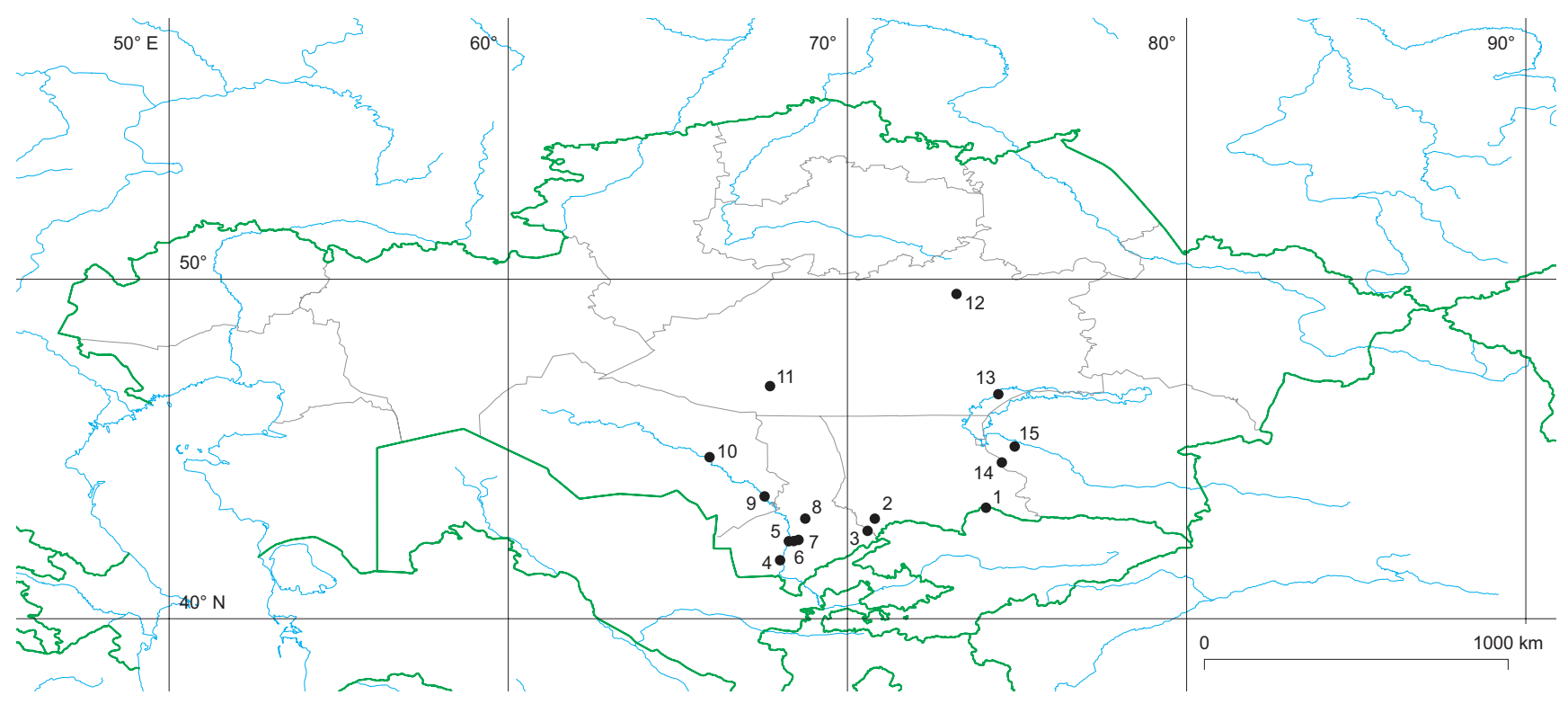

Fig. 1. Map of the localities (numbered as waypoints) visited during the expedition.

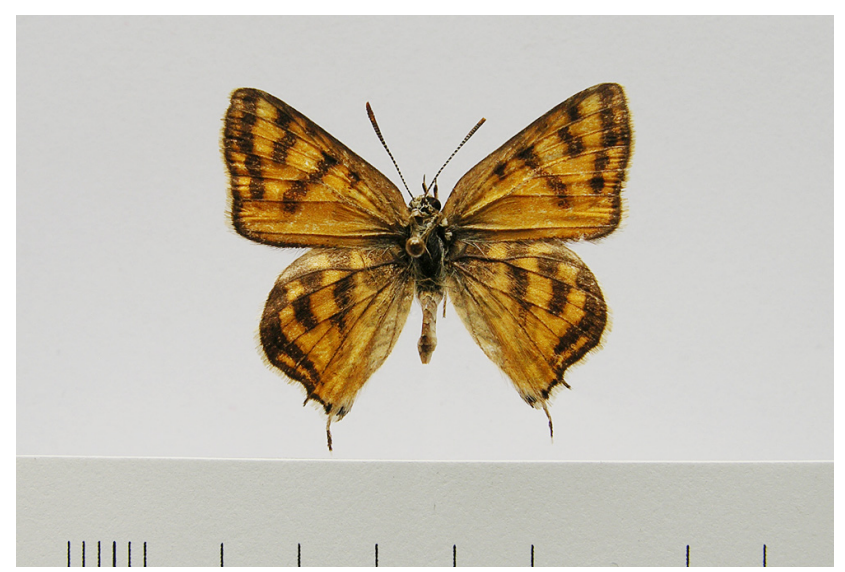

Fig. 2. Cigaritis epargyros, 우.

$\delta \bar{\partial}$. Widespread in the southern part of Kazakhstan (Tshikolovets et al., 2016: 123).

Neolycaena rhymnus (Eversmann, 1832) - [waypoint 10] Kyzylorda Province, Dar'yalyktakyr Plain, $30 \mathrm{~km}$

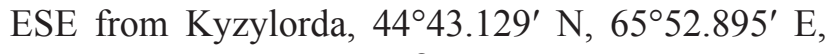
135 m, 24 May 2015 - 1 +; [waypoint 11] Karagandy Province, Betpak-Dala Steppe, $105 \mathrm{~km} \mathrm{~S}$ of Jezkazgan, 46 $50.057^{\prime} \mathrm{N}, 67^{\circ} 41.086^{\prime} \mathrm{E}, 251 \mathrm{~m}, 26$ May

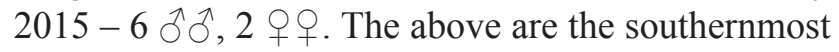
localities in the country, all previously known localities are situated in the northwestern and northeastern parts of Kazakhstan (Tshikolovets et al., 2016: 129).
Lycaena alexandra (Püngeler, 1901) - [waypoint 14] Jambyl Province, Betpak-Dala Steppe, S from Aksuyek Village, $44^{\circ} 33.657^{\prime} \mathrm{N}, 7^{\circ} 35.563^{\prime} \mathrm{E}, 451 \mathrm{~m}, 30$ May $2015-3 \hat{\partial}$. Distributed in the central and eastern parts of Southern Kazakhstan (Tshikolovets et al., 2016: 142).

Plebejus christophi (Staudinger, 1874) - [waypoint 13] Karagandy Province, Balkhash Lake Shore, 10 km E from Gulshat Village, 46³5.600' N, 74²9.275'

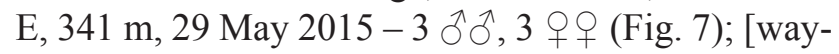
point 15] Almaty Province, Taukum Sands, $3 \mathrm{~km} \mathrm{~W}$ from Topar Village, $45^{\circ} 02.192^{\prime} \mathrm{N}, 74^{\circ} 58.545^{\prime} \mathrm{E}, 363$ $\mathrm{m}, 31$ May $2015-1$ ô, 1 q. Widespread in the southern part of Kazakhstan (Tshikolovets et al., 2016: 177). The first of the above-mentioned localities extends the species distribution further north in the central part of the country.

Plebejus idas (Linnaeus, 1758) - [waypoint 3] South Kazakhstan Province, Boraldaytau Ridge, 3 km ENE of Shakpak Baba Village, $42^{\circ} 31.501^{\prime} \mathrm{N}, 70^{\circ} 35.507^{\prime}$ E, 1099 m, 18 May 2015 - 1 o ; [waypoint 4] South Kazakhstan Province, Syrdarya River Valley, $3 \mathrm{~km}$ S of Kazakhstan Village, $41^{\circ} 38.990^{\prime}$ N, 67 $59.048^{\prime}$ E, $240 \mathrm{~m}, 20$ May $2015-1$ ô, 2 웅. Distributed in the northern and southeastern part of Kazakhstan (Tshikolovets et al., 2016: 181). The second of the above-mentioned localities extends the species distri- 
Notes on the distribution of some species of Lepidoptera in Kazakhstan

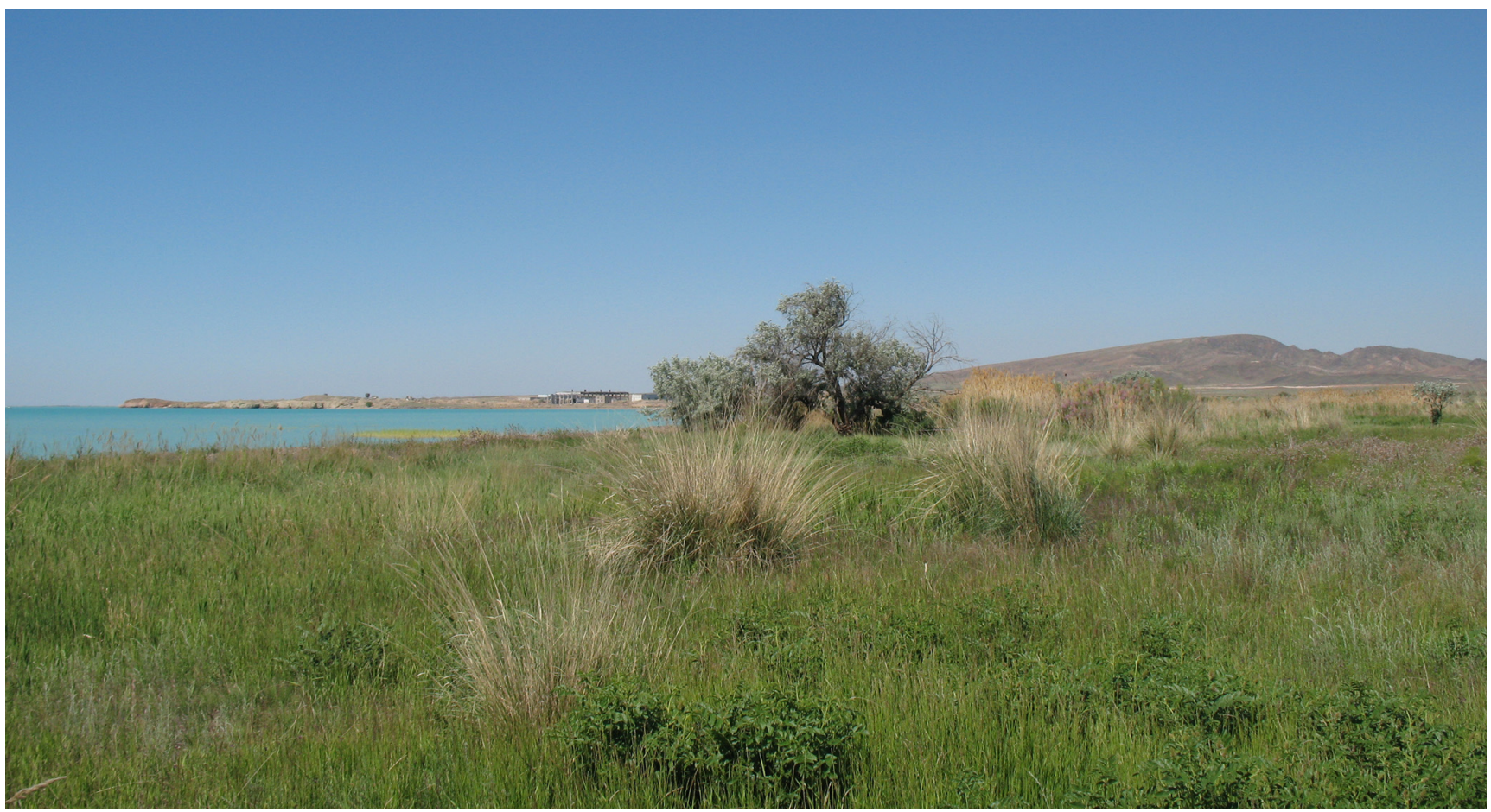

Fig. 3. Western Balkhash Lake Shore, E from Gulshat Village [waypoint 13], habitat of Amata caspia, Plebejus christophi. Photo: N. Simov.

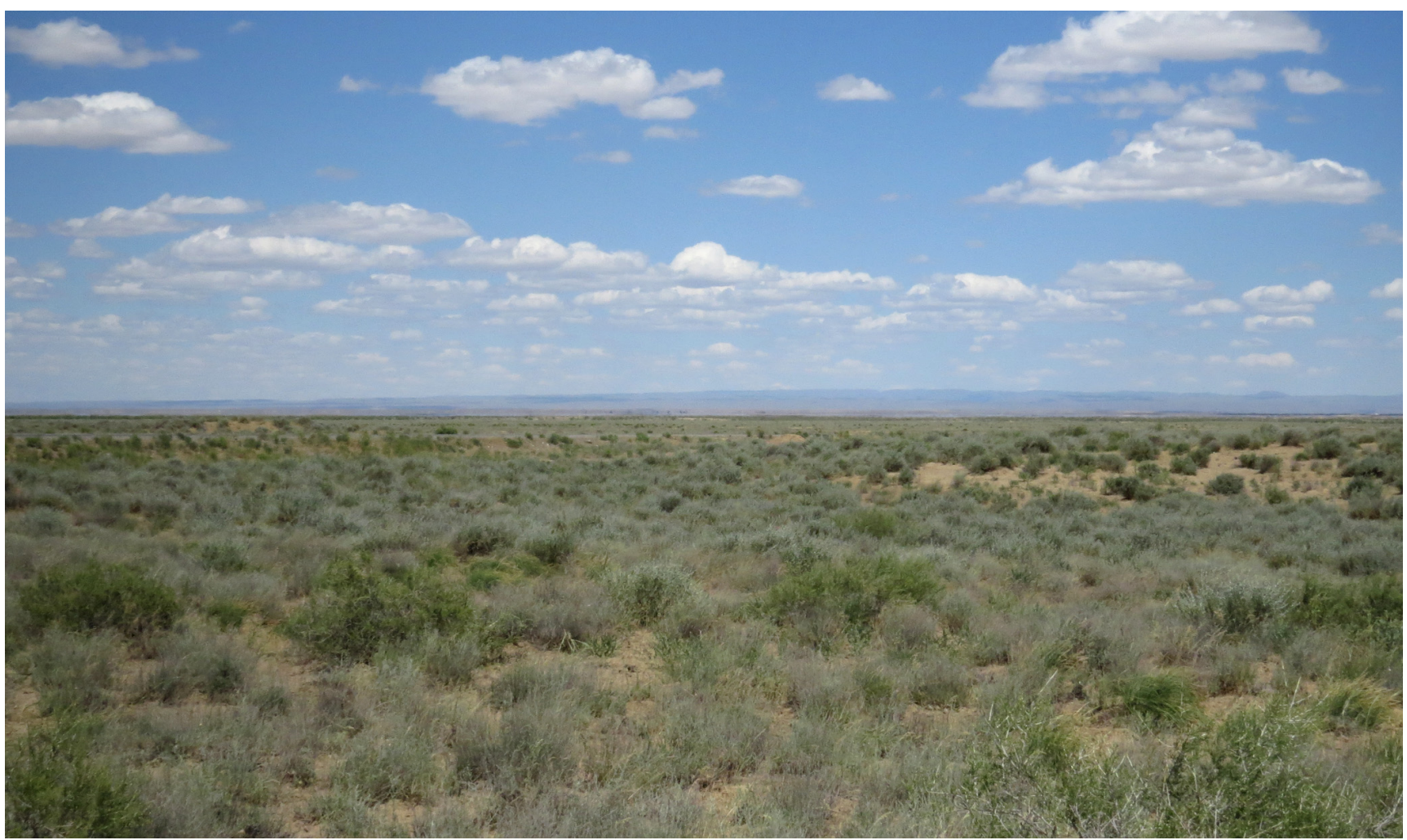

Fig. 4. Border area between Syrdarya Valley and Kyzylkum Desert, WSW of Besh-Aryk Village [waypoint 9], habitat of Cigaritis epargyros. Photo: F. Konstantinov. 
Mario Langourov, Nikolay Simov, Stanislav Abadjiev

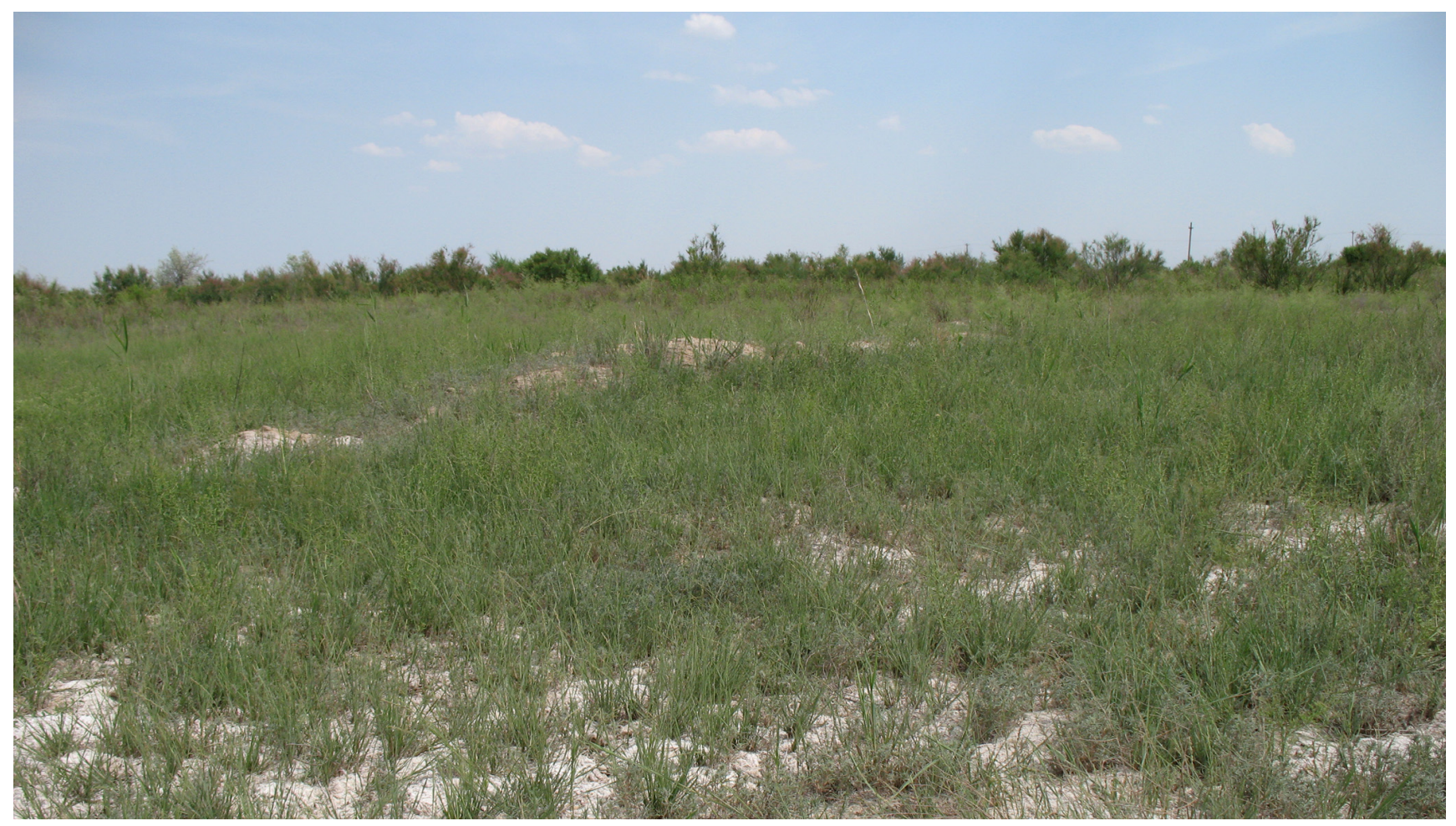

Fig. 5. Saline soil habitats in Syrdarya River Valley, S of Kazakhstan Village [waypoint 4], habitat of Plebejus elvira. Photo: N. Simov.

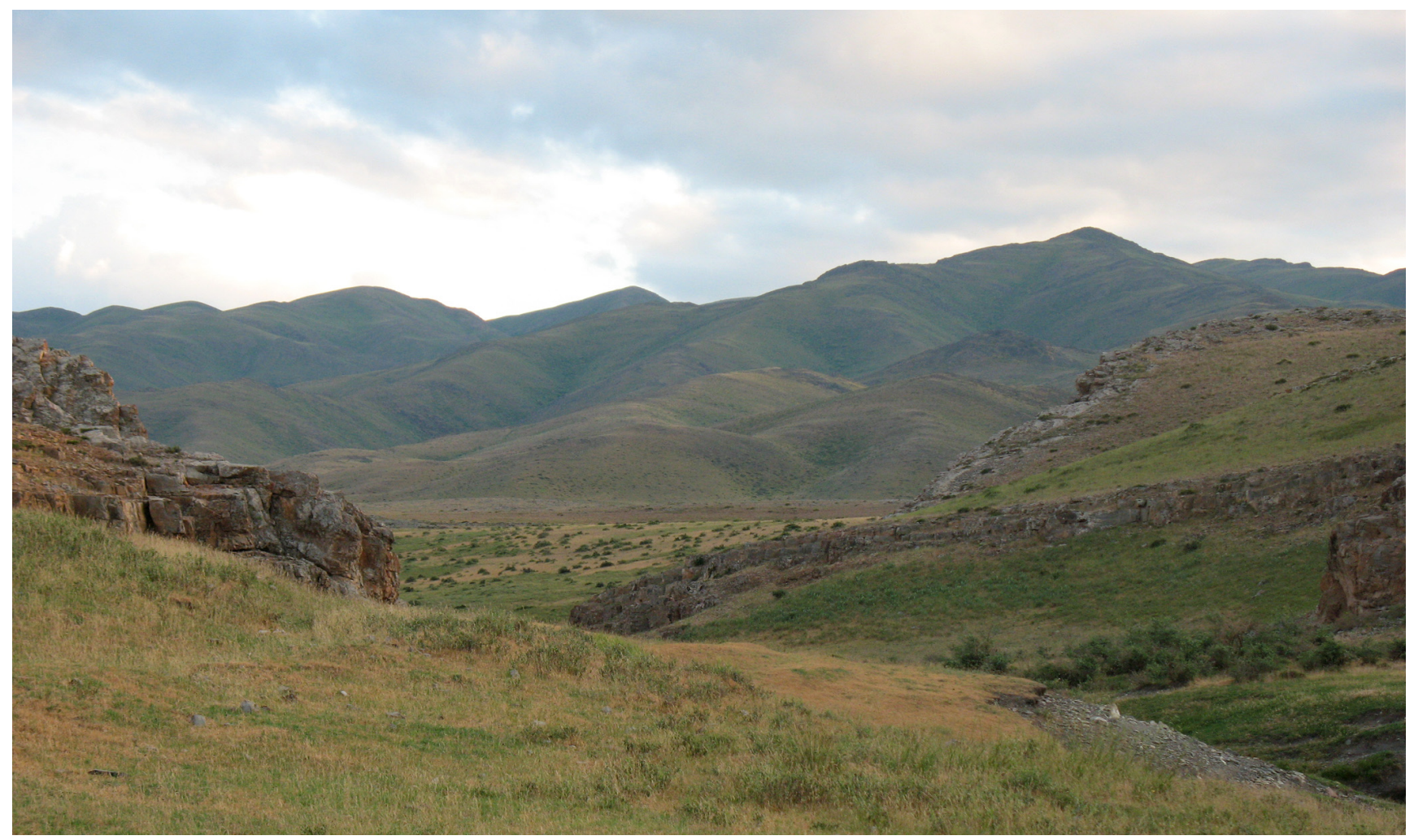

Fig. 6. Karatau Mts, S of Karabastau Village [waypoint 2], habitat of Melanargia parce. Photo: N. Simov. 
Notes on the distribution of some species of Lepidoptera in Kazakhstan

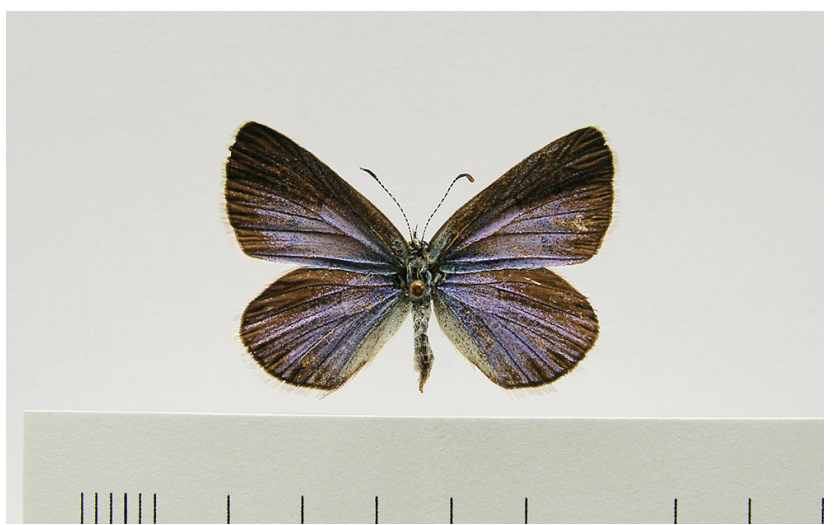

Fig. 7. Plebejus christophi, ㅇ.

bution further west in the central part of the country to Syrdarya River Valley.

Plebejus elvira (Eversmann, 1854) - [waypoint 4] (Fig. 5) South Kazakhstan Province, Syrdarya River

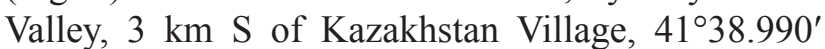

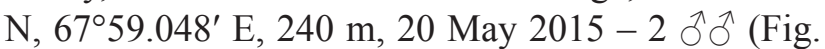
$8)$. Widespread in the southern part of Kazakhstan (Tshikolovets et al., 2016: 191).

\section{Nymphalidae}

Melanargia parce Staudinger, 1882 - [waypoint 2] (Fig. 6) Jambyl Province, Karatau Mts, 4 km S from Karabastau Village, 42 $53.234^{\prime}$ N, $70^{\circ} 48.404^{\prime}$ E, 570 m, 17 May 2015 - 1 ô (Fig. 9). Distributed in the southern part of Kazakhstan, near the border with Kyrgyzstan and Uzbekistan from 800 to $2500 \mathrm{~m}$ (Tshikolovets et al., 2016: 224). This is the lowest locality in this country.

Triphysa phryne (Pallas, 1771) - [waypoint 12] Karagandy Province, Saryarka, $25 \mathrm{~km}$ SSW from Karagandy, Zhumbek Village, $49^{\circ} 34.660^{\prime} \mathrm{N}, 73^{\circ} 14.527^{\prime} \mathrm{E}$, 584 m, 28 May 2015 - 1 §. Widespread in Kazakhstan, except for the southern part of the country near the border with Uzbekistan (Tshikolovets et al., 2016: 251).

Hyponephele lycaon (Rottemburg, 1775) - [waypoint 8] South Kazakhstan Province, Turkestan District, 6 $\mathrm{km}$ W of Shilik Village, $42^{\circ} 53.334^{\prime} \mathrm{N}, 68^{\circ} 44.026^{\prime} \mathrm{E}$, 200 m, 22 May $2015-1$ J , 3 우. Southernmost locality in the country. Previously known localities are

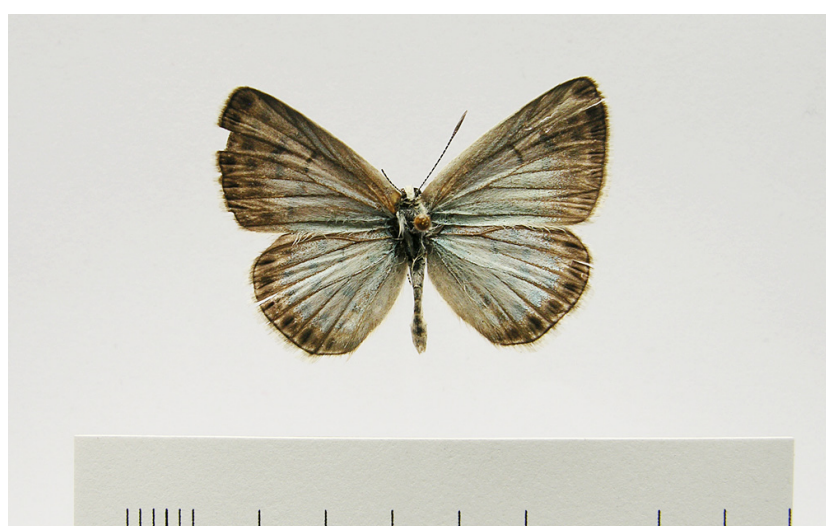

Fig. 8. Plebejus elvira, $\widehat{\jmath}$.

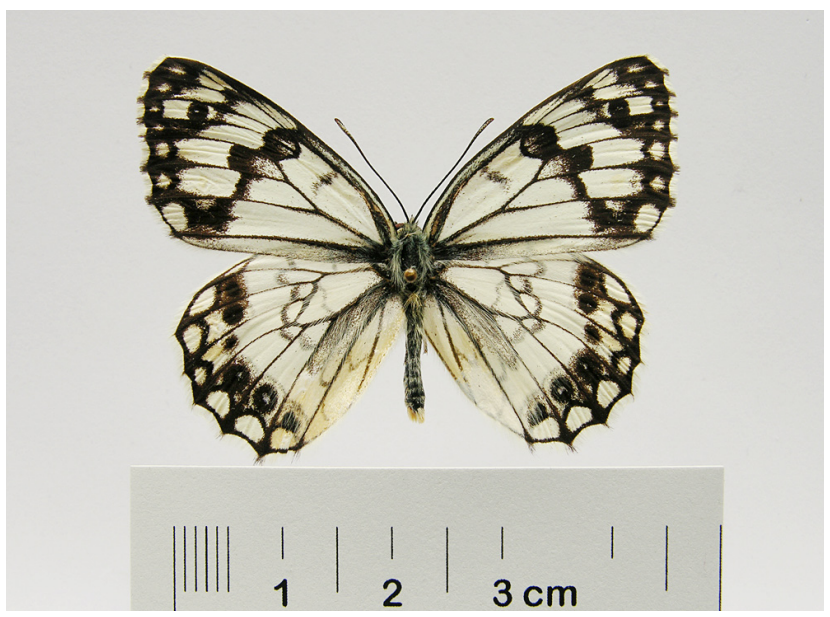

Fig. 9. Melanargia parce, ô.

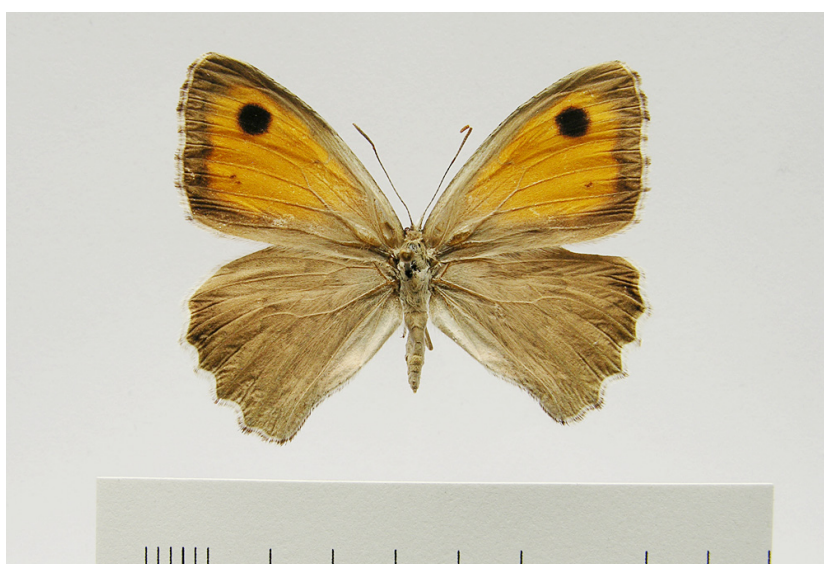

Fig. 10. Hyponephele narica, ㅇ.

situated in the northern and southeastern parts of Kazakhstan (Tshikolovets et al., 2016: 258). 


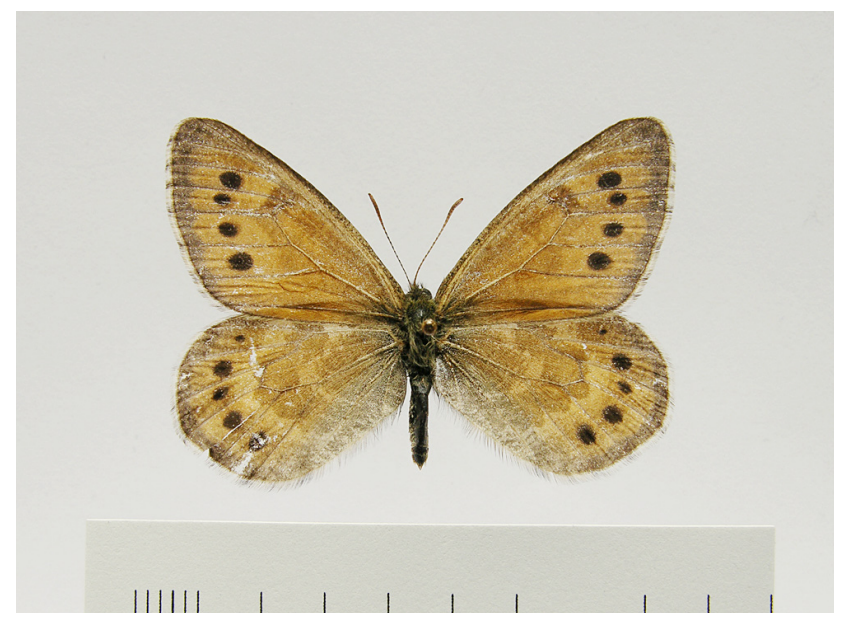

Fig. 11. Oeneis tarpeia, ふึ.

Hyponephele narica (Hübner, [1813]) - [waypoint 10] Kyzylorda Province, Dar'yalyktakyr Plain, 30 km ESE

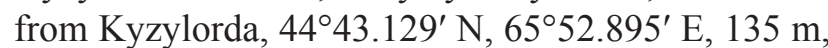
24 May $2015-2$ ổ, 1 오 (Fig. 10). Widespread in the southern part of Kazakhstan (Tshikolovets et al., 2016: 267).

Oeneis tarpeia (Pallas, 1771) - [waypoint 12] Karagandy Province, Saryarka, $25 \mathrm{~km}$ SSW from Karagandy, Zhumbek Village, $49^{\circ} 34.660^{\prime} \mathrm{N}, 73^{\circ} 14.527^{\prime} \mathrm{E}$, $584 \mathrm{~m}, 28$ May $2015-3$ วิ $\widehat{\partial}$ (Fig. 11). Widespread in Northern Kazakhstan, especially in the northeastern part (Tshikolovets et al., 2016: 270).

Chazara enervata (Staudinger, 1881) - [waypoint 6] South Kazakhstan Province, Syrdarya River Valley, $42 \mathrm{~km}$ WSW Arys Village, $42^{\circ} 13.239^{\prime} \mathrm{N}, 68^{\circ} 23.525^{\prime}$ E, 209 m, 21 May 2015 - 1 q. Distributed in the southeastern part of Kazakhstan between 300 and $2500 \mathrm{~m}$ (Tshikolovets et al., 2016: 287).

Melitaea didyma (Esper, [1778]) - [waypoint 1] Jambyl Province, Chu Valley, $8 \mathrm{~km}$ SE from Aksu, $43^{\circ} 12.790^{\prime} \mathrm{N}, 74^{\circ} 07.235^{\prime} \mathrm{E}, 570 \mathrm{~m}, 16$ May $2015-$ 1 q. Widespread in Kazakhstan (Tshikolovets et al., 2016: 321).

Melitaea sibina Alphéraky, 1881 - [waypoint 10] Kyzylorda Province, Dar'yalyktakyr Plain, 30 km ESE

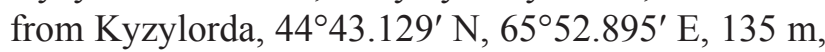
24 May $2015-1 \delta^{\top}$. Distributed in the southern part of Kazakhstan, near the border with Kyrgyzstan and Uzbekistan (Tshikolovets et al., 2016: 330).
Argynnis adippe ([Denis \& Schiffermüller], 1775) - [waypoint 5] South Kazakhstan Province, Syrdarya River Beach, $5 \mathrm{~km}$ WSW of Takhirkol Village, $42^{\circ} 12.958^{\prime} \mathrm{N}, 68^{\circ} 14.673^{\prime} \mathrm{E}, 204 \mathrm{~m}, 20$ May $2015-1$ $\widehat{\sigma}$. Distributed in the northern and eastern parts of Kazakhstan (Tshikolovets et al., 2016: 339). The present record extends the species distribution further west in the central part of the country to Syrdarya River Valley.

\section{Acknowledgments}

We thank Fedor Konstantinov (Saint Petersburg State University, Saint Petersburg), for his valuable help in collecting the material and for providing photos of the habitats.

\section{References}

Ignatyev N.N., Zolotuhin V.V. 2005 A review of syntomids (Lepidoptera: Syntomidae) of Russia and adjacent territories. Part 1. Genus Syntomis Ochsenheimer, 1808. Eversmannia 3-4: 28-55.

Korb S.K., Egorov P.V. 2012 To the study of the butterfly fauna of Kazakhstan: the early spring aspect of the fauna of the basins of the Ili and Sharyn Rivers (Lepidoptera, Papilionoformes). Proceedings of the P.G. Smidovich Mordovian State Nature Reserve 10: 343-347. (In Russian)

Tshikolovets V.V., Kosterin O.E., Gorbunov P.Y., Yakovlev R.V. 2016 The Butterflies of Kazakhstan. Tshikolovets Publications, Pardubice, 448 pp. 